Ann. Biol. anim. Bioch. Biophys., 1978, 18 (4), 937-941.

\title{
Emergence of ovarian 11-deoxycorticosteroid biosynthesis at ovulation time in the sea bass, Dicentrarchus labrax $\mathbf{L}$.
}

\author{
par L. COLOMBO, Paola COLOMBO BELVEDERE, G. ARCARESE * \\ Institute of Animal Biology, University of Padua, \\ Via Loredan 10, 35100 Padua \\ * S.I.R.A.P. Marine Fish Hatchery, Pellestrina, Italy.
}

Summary. Steroidogenesis in the ovary of the teleost Dicentrarchus labrax has been studied in vitro at five different stages : 1) previtellogenic ; 2) postvitellogenic ; 3) postovulatory, one day after HCG-induced spawning ; 4) postovulatory, 9 days after induced spawning ; 5) atretic. Ovarian tissues were incubated with $\left[4-{ }^{14} \mathrm{C}\right]$ pregnenolone and $\left[4-{ }^{14} \mathrm{C}\right]$ progesterone for $6 \mathrm{hr}$ at $15-16^{\circ} \mathrm{C}$. The following metabolites were formed after ovulation : progesterone (from pregnenolone), 11-deoxycorticosterone, 11-deoxycortisol, $17 \alpha$-hydroxyprogesterone, androstenedione, testosterone and estradiol-17 $\beta$. Percentages of conversion were high for 11-deoxycorticosteroids and androgens and low for estradiol-17 $\beta$. Before ovulation, yields of androgens were high at stage 2 but negligible at stage 1. Estradiol-173 and 11-deoxycorticosterone were obtained in small amounts at maturity but could not be detected during quiescence. Atretic ovarian tissue converted pregnenolone to progesterone but it went no further in steroid hormone biosynthesis.

\section{Introduction.}

The biosynthesis of 11-deoxycorticosterone (DOC) and/or 11-deoxycortisol (S), through 21-hydroxylation of progesterone and $17 \alpha$-hydroxyprogesterone, respectively (Orta-Flores ef al., 1976), has been shown to occur in the ovaries of 6 teleost species (Colombo ef al., 1973 ; Colombo and Colombo Belvedere, 1977), two urodeles (Colombo et al., 1977a, b) and 2 reptiles (Colombo ef al., 1974 ; Colombo and Yaron, 1976). The information available, however, was insufficient to establish whether 11deoxycorticosteroid production was in alternative to that of estrogens by competing, for instance, for $\mathrm{C}_{21}$ intermediates, or whether 11-deoxycorticosteroids alternated with estrogens through a shift in ovarian steroidogenesis at a certain stage of the oogenic cycle.

The observation that the teleost aromatizing system was more apparent in the vitellogenic ovary of Gobius jozo than in pre- and post-ovulatory ovaries of Diplodus annularis and Solea impar, while the reverse was true for steroid 21-hydroxylase activity (Colombo and Colombo Belvedere, 1977), could reflect either a sequence of distinct steroidogenic phases or simply a species specificity in ovarian sterold patterns. To avoid 
the latter complication, we decided to use the sea bass, a commercially reared species, to study in vitro the course of ovarian steroid hormone biosynthesis during the reproductive cycle.

\section{Materials and methods.}

Sixteen females of Dicentrarchus labrax (mean standard length : $38.0 \mathrm{~cm} \pm 2.9$ SD ; mean body weight : $994 \mathrm{~g} \pm 225 \mathrm{SD}$ ) were used. Mature or spawned specimens were obtained from the SIRAP Marine Fish Hatchery at Pellestrina whereas nonbreeding animals were captured in coastal lagoons near Venice. Both ovaries were dissected out following pithing of the fish. Five ovarian stages were investigated : 1) quiescent ovary with only previtellogenic oocytes obtained from females caught outside the breeding period in April ; 2) mature or postvitellogenic ovary packed with yolky oocytes and some growing follicles; 3 ) ovary one day after spawning, induced in mature females by injecting $1000 \mathrm{lU} / \mathrm{kg}$ body weight of human chorionic gonadotropin (HCG) ; 4) ovary nine days after induced spawning ; 5) ovary with extensive follicular atresia as found in females confined to low saliniry (5-10 p. 1000) brackish water during ovarian maturation.

Portions of ovarian tissue from animals at the same stage were pooled in ice-cold physiologic medium of the following composition : $187.3 \mathrm{mM} \mathrm{NaCl}, 3.34 \mathrm{mM} \mathrm{KCl}$, $2.30 \mathrm{mM} \mathrm{CaCl}_{2}, 3.98 \mathrm{mM} \mathrm{MgCl}_{2}, 0.37 \mathrm{mM} \mathrm{MgSO}, 1.61 \mathrm{mM} \mathrm{Na}_{2} \mathrm{HPO}_{4}, 0.36 \mathrm{mM}$ $\mathrm{KH}_{2} \mathrm{PO}_{4}, 20.0 \mathrm{mM} \mathrm{NaHCO}, 5.55 \mathrm{mM}$ glucose, phenol red $2 \mathrm{mg} /$ liter. 2-g samples of tissue were then incubated in 50-ml Erlenmeyer flasks containing $1 \mu \mathrm{Ci}$ of either $\left[4-{ }^{14} \mathrm{C}\right.$ ] pregnenolone (specific activity $(\mathrm{SA}): 52.8 \mathrm{mCi} / \mathrm{mmole}$ ) or $\left[4-{ }^{14} \mathrm{C}\right]$ progesterone (SA : $52.8 \mathrm{mCi} / \mathrm{mmole}$ ) previously dissolved in $200 \mu \mathrm{l}$ of propylene glycol, plus $20 \mathrm{ml}$ of medium. Incubations were carried out in a Dubnoff metabolic shaker for $6 \mathrm{hr}$ at $15-16^{\circ} \mathrm{C}$. Aliquots of $2 \mathrm{ml}$ were withdrawn from the incubation medium after $7.5,15$, $30,60,120,240$ and $360 \mathrm{~min}$. and replaced by an equal volume of fresh medium without precursor. At the end of incubation, the medium was separated from the tissue. Metabolism was terminated by mixing thoroughly with 3 volumes of ethanol.

Before extraction, suitable amounts of carrier and tritiated steroids were added to samples. Metabolites were then extracted, chromatographed bidimensionally on thinlayer plates, autoradiographed, eluted and identified by their isopolarity and isomorphicity with authentic steroids, as previously described (Colombo and Colombo Belvedere, 1977).

\section{Results.}

The following compounds were formed from both precursors by ovulated ovarian tissues (stages 3 and 4) : progesterone (from pregnenolone), 11-deoxycorticosterone, 11-deoxycortisol, $17 \alpha$-hydroxyprogesterone, androstenedione, testosterone and estradiol-17 $\beta$. The steroidogenic pattern was not greatly affected by the time interval elapsed from spawning (figs. 3 and 4 ), despite the fact that the involution of non-ovulated oocytes was more advanced after 9 days. The release of the above metabolites in the medium during incubation with either precursor was measured by the integrated 
values of their yield vs time curves: it was high for 11-deoxycorticosteroids $(S>D O C)$ and androgens (testosterone $>$ androstenedione) but low for estradiol-17 $\beta$.

Before ovulation, accumulation of androgens in the incubation medium was high at stage 2 but negligible at stage 1. Estradiol-17 $\beta$ and DOC (but not $S$ ) were obtained in small amounts at maturity but could not be detected during quiescence (figs. 1 and 2). On the other hand, the production of $17 \alpha$-hydroxyprogesterone was always conspicuous from stages 1 to 4, especially with progesterone as a precursor. Metabolite yields in the incubated tissues were correlated according to the same patterns outlined for the
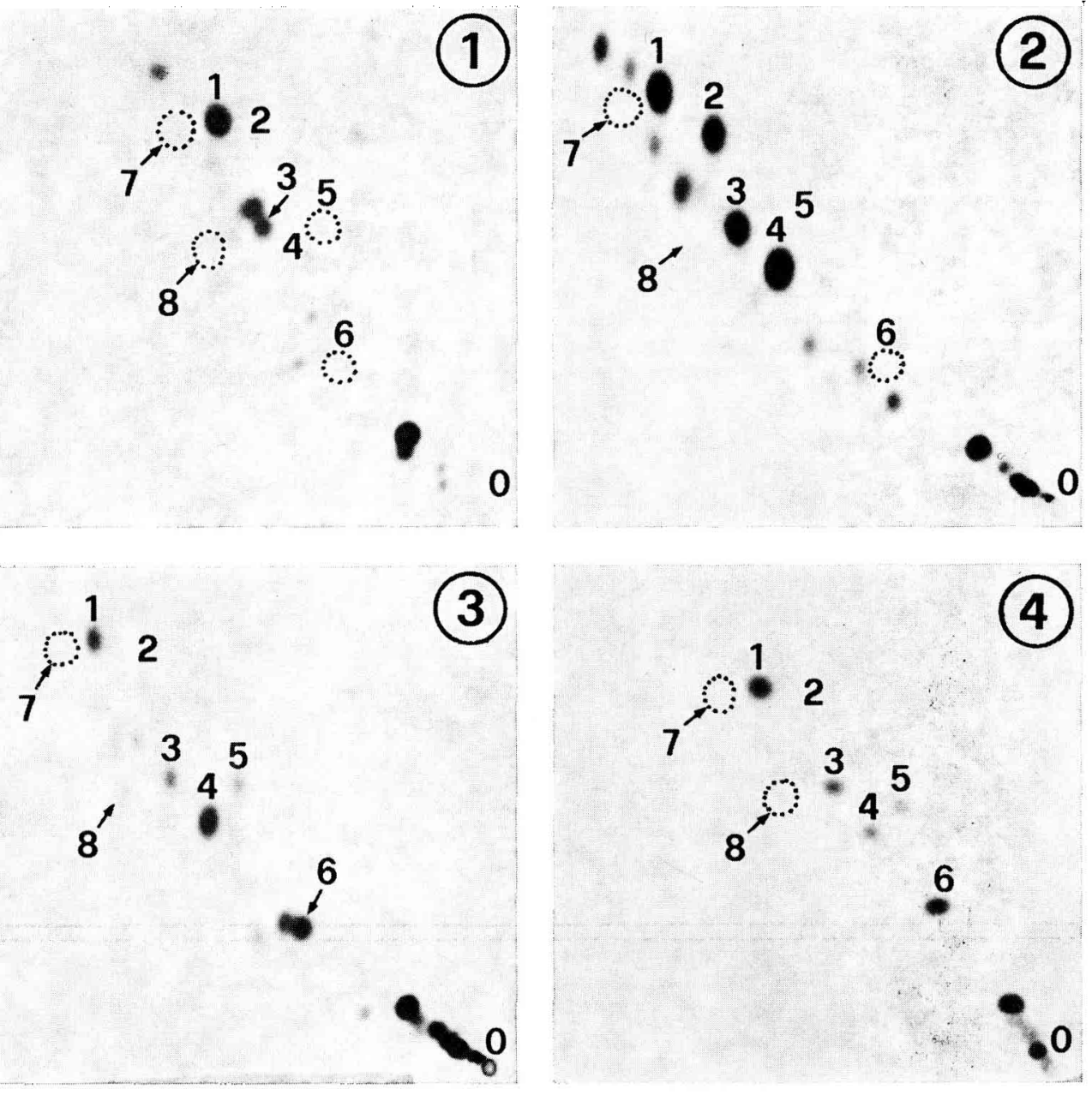

FIG. 1-4. - Autoradiographs of thin-layer chromotographic profiles of metabolites released in the medium after 6-hr incubation of sea bass ovarian tissue at quiescence (fig. 1), at maturity (fig. 2), one day after deposition (fig. 3) and 9 days after deposifion (fig. 4) with $\left[4-{ }^{14} \mathrm{C}\right]$ progesterone. (0) chromatographic origin ; (1) progesterone ; (2) androstenedione ; (3) $17 \alpha$-hydroxyprogesterone ; (4) testosterone ; (5) 11-deoxycorticosterone ; (6) 11-deoxycortisol ; (7) estrone ; (8) estradiol-17 $\beta$. Dotted circles indicate the position of carrier steroids associated with very little or no $\left[{ }^{14} \mathrm{C}\right]$ label. 
media. Tissues, however, showed greater yields of unidentified compounds of low and intermediate polarity.

At stage 5, atretic ovarian tissue converted pregnenolone to progesterone but was unable to perform further steps for steroid hormone biosynthesis. Radioactivity was instead channelled along other transformation routes but their products could not be characterized.

\section{Discussion.}

The present work demonstrates that the following steroid-converting enzymes may contribute to the ovarian steroid profiles of $D$. labrax : $3 \beta$ - and $17 \beta$-hydroxysteroid dehydrogenases, 5-ene-ketosteroid isomerase, $17 \alpha, 20-\mathrm{C}_{21}$-desmolase, steroid $17 \alpha$ - and 21-hydroxylases and aromatizing system. Interestingly, the testicular tissue in the same species was devoid of the last two enzymatic activities (Colombo ef al., 1978a). The ovarian location of steroid 21-hydroxylase in the sea bass, a member of the family Serranidae, confirms similar findings in 3 other families of the order Perciformes (Colombo et al., 1973 ; Colombo and Colombo-Belvedere, 1977).

The changing patterns of steroid metabolism from ovarian quiescence to the postovulatory stage suggests that steroidogenic shifts occur in the ovary of $D$. labrax during the oogenic cycle making androgen intermediates more available for estrogen biosynthesis during follicular growth and causing a rise in 11-deoxycorticosteroid formation around the time of ovulation.

The former change confirms the role of estrogens in the promotion of hepatic synthesis and release of vitellogenin, as documented in fish by recent reports (Plack et al., 1971 ; Campbell and Idler, 1976). On the other hand, the induction of steroid 21-hydroxylase activity concomitantly with spawning fits very well with the fact that in a wide spectrum of steroid compounds, DOC and $S$ were the most potent inducers in vitro of meiotic maturation in goldfish (Jalabert ef al., 1973) and in catfish (Goswami and Sundararaj, 1974). These observations cannot be reconciled, however, with the model proposed by Indian workers (Goswami ef al., 1974) in which 11-deoxycorticosteroids are produced in the interrenal under gonadotropin stimulation and act on the ovary.

A last comment should be made on the extensive atresia likely to result from prolonged gonadotropin deprivation. In this case, suppression of ovarian endocrine activity seems to parallel the involution of gametic elements and the phagocytic conversion of follicular cells.

Symposium sur la Reproduction des Poissons

Paimpont, France, 19-21 septembre 1977.

Acknowledgements. - Aided by grant 76.01116.04 from the National Research Council (CNR) of Italy through the sponsorship of the Instifute of Marine Biology of Venice.

Résumé. La stéroïdogenèse de l'ovaire du téléostéen Dicentrarchus labrax a été étudiée in vitro à 5 stades différents : 1) prévitellogenèse, 2) postvitellogenèse, 3) post-ovulation, 1 jour après la fraie induite par HCG, 4) post-ovulation, 9 jours après la fraie induite, 5) 
atrésie. Les tissus ovariens sont incubés avec $\left[4-{ }^{14} \mathrm{C}\right]$ prégnenolone et $\left[4-{ }^{14} \mathrm{C}\right]$ progestérone pendant $6 \mathrm{~h}$ à $15-16^{\circ} \mathrm{C}$. Les métabolites suivants se forment après ovulation : progestérone (à partir de prégnenolone), 11-desoxycorticostérone, 11-desoxycortisol, $17 \alpha$-hydroxyprogestérone, androsténedione, testostérone et ostradiol-173. Avant l'ovulation, les productions d'androgènes sont élevées au stade 2 , mais négligeables au stade 1 . L'cestradiol-17 $\beta$ et la 11-désoxycorticostérone sont obtenus en faible quantité à maturité, mais ne peuvent être détectés durant la phase de repos sexuel. Le tissu ovarien atrétique convertit la prégnenolone en progestérone mais la biosynthèse des hormones stéroïdes ne va pas au-delà.

\section{References}

CAMPBELL C. M., IDLER D. R., 1976. Hormonal control of vitellogenesis in hypophysectomized winter flounder (Pseudopleuronectes americanus Walbaum). Gen. comp. Endocrinol., 28, 143-150.

COLOMBO L., BERN H. A., PIEPRZYK J., JOHNSON D. W., 1973. Biosynthesis of 11-deoxycorticosteroids by teleost ovaries and discussion of their possible role in oocyte maturation and ovulation. Gen. comp. Endocrinol., 21, 168-178.

COLOMBO L., COLOMBO BELVEDERE P., 1977. Gonadal steroidogenesis in teleost fishes. Invest. Pesq., 41, 147-164.

COLOMBO L., COLOMBO BELVEDERE P., ARCARESE G., 1978a. Gonadal steroidogenesis and gametogenesis in teleost fish. - A study on the sea bass, Dicentrarchus labrax L. Boll. Zool. (in press).

COLOMBO L., COLOMBO BELVEDERE P., PRANDO P., 1977a. Biosynthesis of 11-deoxycorticosteroids and estrogens by the ovary of the urodeles Triturus alpestris alpestris Laur. and Salamandra salamandra salamandra L. Boll. Zool., 44, 123-125.

COLOMBO L., COLOMBO BELVEDERE P., PRANDO P., SCAFFAI P., CISOTTO T., 1977b. Biosynthesis of 11-deoxycorticosteroids and androgens by the ovary of the newt Triturus alpestris alpestris Laur. Gen. comp. Endocrinol., 33, 480-495.

COLOMBO L., YARON Z., 1976. Steroid 21-hydroxylase activity in the ovary of the snake Storerio dekayi during pregnancy. Gen. comp. Endocrinol., 28, 403-412.

COLOMBO L., YARON Z., DANIELS E., BELVEDERE P., 1974. Biosynthesis of 11-deoxycorticosterone by the ovary of the yucca night lizard, Xantusia vigilis. Gen. comp. Endocrinol., 24, 331-337.

GOSWAMI S. V., SUNDARARAJ B. I., 1974. Effects of $C_{18}, C_{19}$, and $C_{21}$ steroids on in vitro maturation of oocytes of the catfish, Heteropneustes fossilis (Bloch.) Gen. comp. Endocrinol., 23, 282-283.

GOSWAMI S. V., SUNDARARAJ B. I., DONALDSON E. M., 1974. In vitro maturation response of oocytes of the catfish Heteropneusfes fossilis (Bloch) to salmon gonadotropin in ovary-head kidney co-colture. Can. J. Zool., 52, 745-748.

JALABERT B., BRY C., SZÖLLOOSI D., FOSTIER A., 1973. Etude comparée de l'action des hormones hypophysaires et stéroïdes sur la maturation in vitro des ovocytes de la truite et du carassin (poissons téléostéens). Ann. Biol. anim. Bioch. Biophys., 13, 59-71.

ORTA-FLORES Z., CANTU J. M., DOMINGUEZ O. V., 1976. Reciprocal interactions of progesterone and $17 \alpha$-hydroxyprogesterone as exogenous substrates of rat adrenal 21-hydroxylase. J. Steroid Biochem., 7, 761-767.

PLACK P. A., PRITCHARD D. J., FRASER N.W., 1971. Egg proteins in cod serum : Natural occurrence and induction by injection of cstradiol-3-benzoate. Biochem. J., 121, 847-856. 